\title{
Effect of Seed Treatment and Foliar Crop Protection Products on Sudden Death Syndrome and Yield of Soybean
}

\author{
Yuba R. Kandel, ${ }^{1}$ Carl A. Bradley, ${ }^{2}$ Martin I. Chilvers, ${ }^{3}$ Febina M. Mathew, ${ }^{4}$ Albert U. Tenuta, ${ }^{5}$ Damon L. Smith, ${ }^{6}$ \\ Kiersten A. Wise, ${ }^{2}$ and Daren S. Mueller ${ }^{1, \dagger}$ \\ ${ }^{1}$ Department of Plant Pathology and Microbiology, Iowa State University, Ames 50011, U.S.A. \\ ${ }^{2}$ Department of Plant Pathology, University of Kentucky Research and Education Center, Princeton 42445, U.S.A. \\ ${ }^{3}$ Department of Plant, Soil and Microbial Sciences, Michigan State University, East Lansing 48824, U.S.A. \\ ${ }^{4}$ Department of Agronomy, Horticulture and Plant Science, South Dakota State University, Brookings 57007, U.S.A. \\ ${ }^{5}$ Ontario Ministry of Agriculture, Food, and Rural Affairs, Ridgetown, ON NOP2C0, Canada \\ ${ }^{6}$ Department of Plant Pathology, University of Wisconsin-Madison, Madison, 53706, U.S.A.
}

\begin{abstract}
Sudden death syndrome (SDS), caused by Fusarium virguliforme, is an important soilborne disease of soybean. Risk of SDS increases when cool and wet conditions occur soon after planting. Recently, multiple seed treatment and foliar products have been registered and advertised for management of SDS but not all have been tested side by side in the same field experiment at multiple field locations. In 2015 and 2016, seed treatment fungicides fluopyram and thiabendazole; seed treatment biochemical pesticides citric acid and saponins extract of Chenopodium quinoa; foliar fungicides fluoxastrobin + flutriafol; and an herbicide, lactofen, were evaluated in Illinois, Indiana, Iowa, Michigan, South Dakota, Wisconsin, and Ontario for SDS management. Treatments were tested on SDS-resistant and -susceptible cultivars at each location. Overall, fluopyram provided the highest

reduced the foliar disease index (FDX) by over $50 \%$ in both resistant and susceptible cultivars and provided $8.9 \%$ yield benefit in susceptible cultivars and $3.5 \%$ yield benefit in resistant cultivars compared with the base seed treatment (control). In 2016, fluopyram reduced FDX in both cultivars by over $40 \%$ compared with the base seed treatment. For yield in 2016, treatment effect was not significant in the susceptible cultivar while, in the resistant cultivar, fluopyram provided $3.5 \%$ greater yield than the base seed treatment. In this study, planting resistant cultivars and using fluopyram seed treatment were the most effective tools for SDS management. However, plant resistance provided an overall better yieldadvantage than using fluopyram seed treatment alone. Effective seed treatments can be an economically viable consideration to complement resistant cultivars for managing SDS
\end{abstract} level of control of root rot and foliar symptoms of SDS among all the treatments. Foliar application of lactofen reduced foliar symptoms in some cases but produced the lowest yield. In 2015, fluopyram
Keywords: chemical, cultivar/resistance, disease management, field crops, fungi, oilseeds and legumes.
Sudden death syndrome (SDS) is one of the most destructive diseases of soybean (Glycine max (L) Merr.) in the United States and Canada (Allen et al. 2017; Koenning and Wrather 2010; Wrather and Koenning 2009; Wrather et al. 2010). The disease was first observed in Arkansas in 1971 (Hirrel 1983) and has since spread to nearly all major soybean-growing states in the United States and to Ontario, Canada (Anderson and Tenuta 1998; Hartman et al. 2015a,b).

In the United States and Canada, Fusarium virguliforme is the primary pathogen that causes SDS (Aoki et al. 2003; Hartman et al. 2015b). F. virguliforme resides in soil as thick-walled chlamydospores or in crop residue and on the cysts of soybean cyst nematode $(\mathrm{SCN})$ as mycelium. The disease cycle begins with the colonization of the soybean root soon after the radicle emerges from seed under wet and cool conditions (Gongora-Canul and Leandro 2011; Huang and Hartman 1998; Scherm and Yang 1996; Wang et al. 2019). These initial root infections cause root rot, reducing the ability of the root to absorb water and nutrients

${ }^{\dagger}$ Corresponding author: D. S. Mueller; E-mail: dsmuelle@iastate.edu

Funding: The research was partially funded by the Soybean Checkoff through the North Central Soybean Research Program, Bayer CropScience, BASF, and The Grain Farmers of Ontario, which obtained funding through the Ontario Farm Innovation Program, a component of Growing Forward.

The author(s) declare no conflict of interest.

Accepted for publication 18 February 2019.

(C) 2019 The American Phytopathological Society from the soil. The fungus also produces toxins that translocate through the xylem from the roots to the foliage, resulting in foliar symptoms (Brar et al. 2011; Chang et al. 2016; Pudake et al. 2013). Foliar symptoms are characterized by interveinal chlorosis and necrosis, followed by premature defoliation. In severe cases, flower and pod abortion and premature plant death may occur (Hartman et al. 2015b).

Host resistance is an effective tactic for SDS management. However, no lines with complete resistance have been identified in the soybean germplasm, and currently available commercial cultivars are only partially resistant to this disease. Resistance to SDS is polygenic, governed by quantitative trait loci (QTL), and, as a result, developing cultivars with improved SDS resistance is challenging (Brzostowski et al. 2018; Chang et al. 2018). When conditions are very favorable for SDS in a field infested with $F$. virguliforme, partial resistance may not prevent yield loss. Several cultural practices such as planting date, crop rotation, and tillage have been examined for their role in reducing SDS severity but the effects of these practices on SDS are not consistent or require further study (Kandel et al. 2016 a,b, 2019; Leandro et al. 2012, 2018; Marburger et al. 2016; Vosberg et al. 2017). SCN (Heterodera glycines) management is also important, because these nematodes have been found to play a role in increasing SDS severity (Kandel et al. 2017; McLean and Lawrence 1993; Melgar et al. 1994; Roy et al. 1989; Scherm et al. 1998; Xing and Westphal 2006); however, crop rotations with corn, which reduces SCN populations in fields over time, do not appear to help with management of SDS (Navi and Yang 2016a).

Previous studies (Gaspar et al. 2017; Kandel et al. 2016a,b, 2017, 2018a,b; Vosberg et al. 2017) showed that fluopyram fungicide as a seed treatment, a succinate dehydrogenase inhibitor (SDHI; 
Fungicide Resistance Action Committee [FRAC] group 7), reduced foliar and root symptoms of SDS and resulted in greater yields when compared with standard commercial base seed treatments that included a combination of fungicide, insecticide, and nematistat active ingredients. A seed treatment containing the active ingredient fluopyram known as ILeVO (BASF, Research Triangle Park, NC, U.S.A.) became commercially available for SDS management for U.S. soybean growers in 2015 and for Canadian farmers in 2017. Since 2015, seed treatments, including thiabendazole (Mertect 340-F; Syngenta Crop Protection, Greensboro, NC, U.S.A.), a methyl benzimidazole carbamate (FRAC group 1) fungicide, as well as foliar fungicides with different active ingredients such as fluoxastrobin + flutriafol (Fortix; Cheminova, Inc., Research Triangle Park, NC, U.S.A.), a premix of quinone outside inhibitor (FRAC group 11) and a demethylation inhibitor (FRAC group 3 ) are now registered and being marketed for SDS management.

In addition to chemical fungicides, biopesticides such as citric acid (Procidic; Greenspire Global, Inc., Des Moines, IA, U.S.A.) and saponins extracted from Chenopodium quinoa (Heads Up; Heads Up Plant Protectant, Inc., Saskatchewan, Canada) and Pasteuria nishizawae Pn1 (Clariva PN; Syngenta Crop Protection) are also labeled for SDS management. Citric acid has been reported to have broadspectrum bactericidal and fungicidal activity. Saponins act by activating systemic acquired resistance in plants and have been shown to be effective against SDS and Sclerotinia stem rot (caused by Sclerotinia sclerotiorum) in soybean in one trial (Navi and Yang 2016b). In addition to products that are specifically labeled for SDS management, the herbicide lactofen, which can reduce Sclerotinia stem rot in soybean (Dann et al. 1999; Huzar-Novakowiski et al. 2017; Willbur et al. in press), was also evaluated in this study. Examining labeled products side by side under diverse field environments and geographic regions is needed to determine which products are most efficacious against SDS. There is also a need to find chemistries with activity against SDS because reliance on fluopyram alone as a sole active ingredient may not be a sustainable SDS management tool due to the risk of fungicide resistance that can occur with SDHI fungicides (FRAC 2017; Wang et al. 2017).

The objectives of this study were to (i) examine the response of cultivars with different levels of SDS resistance across a broad geographic area and (ii) evaluate how seed treatment and foliar products affect soybean plant populations, root rot and foliar symptoms of SDS, and yield in SDS-resistant and -susceptible cultivars.

\section{Materials and Methods}

Field experiments were established at seven locations in both 2015 and 2016. In 2015, experiments were conducted near Ames and Roland, IA; Decatur, MI; Dixon Springs, IL; and Wanatah, IN in the United States; and Highgate and Rodney, ON, Canada. In 2016, experiments were conducted near Ames and Roland, IA; Arlington, WI; Beresford, SD; Decatur, MI; and Wanatah, IN in the United States; and Highgate, Ontario, Canada (Table 1). In total, eight fungicide treatments, including commercial base seed treatments as controls, were tested at each location. The list of treatments with their application time and rates is shown in Table 2. In brief, treatments included (i) a commercial base seed treatment from Syngenta Crop Protection LLC (Syngenta base) that included a combination of insecticide and fungicide active ingredients: thiamethoxam + mefenoxam + fludioxonil + sedaxane (CruiserMaxx Vibrance); (ii) Syngenta base $+P$. nishizawae Pn1 (Clariva; Syngenta Crop Protection LLC) + thiabendazole (Mertect 340-F; Syngenta Crop Protection LLC); (iii) a commercial base seed treatment from Bayer CropScience (Bayer base) that included a combination of fungicide and insecticide active ingredients: prothioconazole + penflufen + metalaxyl (Evergol Energy), metalaxyl (Allegiance), and imidacloprid + ethoxylated polyarylphenol (Gaucho); (iv) Bayer base + fluopyram (ILeVO; BASF) + clothianidin + Bacillus firmus (Poncho VOTiVO; BASF); (v) Bayer base + saponins extracted from $C$. quinoa (Heads Up; Heads Up Plant Protectants, Inc.); (vi) Bayer base followed by (fb) lactofen (Cobra; Valent U.S.A. Corporation, Walnut Creek CA, U.S.A.); (vii) Bayer base fb fluoxastrobin + flutriafol (Fortix; Cheminova, Inc.); and (viii) Bayer base fb citric acid (Procidic; Greenspire Global, Inc.). Lactofen and fluoxastrobin + flutriafol were applied at R1 (beginning bloom) and citric acid was applied at R1 and R4 (full pod) growth stages. Lactofen was applied with crop oil concentrate at $1,169 \mathrm{ml} / \mathrm{ha}$. A nontreated control was not included in this experiment because the fungicide active ingredients used in commercial base seed treatments from the two companies target seedling diseases and have no efficacy on SDS (Weems et al. 2015). Therefore, commercial base seed treatments served as surrogates for a control treatment. Each

Table 1. Field locations, soybean cultivars, seeding rates, and other field activities performed in experiments conducted in the states of Illinois, Indiana, Iowa, Michigan, South Dakota, and Wisconsin in the United States and Ontario, Canada during 2015 and 2016

\begin{tabular}{llccc}
\hline Year, location & \multicolumn{1}{c}{ Cultivar $^{\mathbf{x}}$} & SR (seed/ha) & Infested $^{\mathbf{z}}$ & Previous crop \\
\hline 2015 & & & & Irrigated \\
Ames, IA & S: P25T51R (5), R: P93Y83 (7) & 308,881 & Yes & Corn \\
Roland, IA & S: P25T51R (5), R: P93Y83 (7) & 308,881 & No & Corn \\
Dixon Springs, IL & S: P33T72R (5), R: P36T86R (8) & 345,947 & Yes & Corn \\
Wanatah, IN & S: P25T51R (5), R: P93Y83 (7) & 345,947 & Yes & Corn \\
Decatur, MI & S: P25T51R (5), R: P93Y83 (7) & 387,955 & No & Corn \\
Highgate, ON & S: P25T51R (5), R: P93Y83 (7) & 637,222 & No & Corn \\
Rodney, ON & S: P25T51R (5), R: P93Y83 (7) & 637,222 & No & Soybean \\
2016 & & & Yes \\
Ames, IA & S: P22T41R2 (3), R: P22T69R (7) & 308,881 & Yes & No \\
Roland, IA & S: P22T41R2 (3), R: P22T69R (7) & 308,881 & No & Corn \\
Wanatah, IN & S: P22T41R2 (3), R: P22T69R (7) & 345,947 & Yes & Corn \\
Decatur, MI & S: P22T41R2 (3), R: P22T69R (7) & 387,955 & No & Corn \\
Beresford, SD & S: P22T41R2 (3), R: P22T69R (7) & 407,723 & No & Yes \\
Arlington, WI & S: P22T41R2 (3), R: P22T69R (7) & 345,947 & Yes & Corn \\
Highgate, ON & S: P22T41R2 (3), R: P22T69R (7) & 637,222 & No & Corn \\
\hline
\end{tabular}

${ }^{x}$ Cultivar and sudden death syndrome (SDS) ratings in parenthesis: $\mathrm{S}=$ susceptible to SDS, $\mathrm{R}=$ resistant to SDS based on company standard, and $\mathrm{P}=\mathrm{Pioneer}$; cultivar ratings were provided on a 1 -to-9 scale with $1=$ susceptible.

y $\mathrm{SR}=$ seeding rate.

${ }^{\mathrm{z}}$ Field infestation was done at planting in Illinois, Indiana, Iowa, and Wisconsin. In Illinois, ground sorghum infested with Fusarium virguliforme isolate Mont-1 was applied at $4.1 \mathrm{~cm}^{3}$ per linear meter of row. In Indiana, sorghum inocula infested with the mixture of $F$. virguliforme isolates NRRL 22823, 00-11-183, and INS12-10 \#3-1 were applied at $4.2 \mathrm{~g} / \mathrm{m}$. In Iowa, field experiments were inoculated with locally originated $F$. virguliforme isolate NE305 at $8.3 \mathrm{~g}$ of infested sorghum per linear meter of row. In Wisconsin, isolates Fv05, FvO6, and Fv07 were applied together at a rate of $8.2 \mathrm{~g}$ of infested sorghum per linear meter of row. 
treatment was tested on susceptible and resistant cultivars at each location (Table 1). Pro-Ized red seed colorant and finisher (Peridiam Precise 1010; Bayer CropScience) was added on each seed treatment at the rate of 32.5 and $65 \mathrm{ml}$, respectively, per $100 \mathrm{~kg}$ of seed. Seed were treated with a Hege bowl seed treater (Wintersteiger, Salt Lake City, UT, U.S.A.).

Resistant and susceptible cultivars were tested separately in field experiments (Table 1). Treatments were arranged within each cultivar in a randomized complete block design with four or five replicates. Experiments were established in fields with a history of SDS or fields were infested with $F$. virguliforme isolates that originated locally. F. virguliforme inoculum was prepared by infesting autoclaved grain sorghum or oat grains following a previously published protocol (de Farias Neto et al. 2006). Infested grain sorghum or oat grains were applied in-furrow at planting. Individual plots were 5.3 to $9.1 \mathrm{~m}$ long and 4 to 6 rows wide with 38.1 - to $76.2-\mathrm{cm}$ interrow spacing. Corn was the previous crop in all the locations except in Rodney, Ontario, where soybean was planted in the previous year. Fields were cultivated in the spring with a field cultivator in all locations. Research trials were irrigated at the Illinois location, one location in Iowa, and at the Michigan location. Irrigation and other field operation details are provided in Table 1. Briefly, in Illinois, drip irrigation was started from the beginning of June and ran for 6 weeks, with approximately $2.5 \mathrm{~cm}$ of water delivered weekly. In Indiana in 2016, overhead irrigation was started on 20 June and trials were watered at weekly intervals until 8 August. About $2.5 \mathrm{~cm}$ water was applied each time. In Iowa, drip irrigation was set up during the first week of August and ran three to four times each week; approximately $2.5 \mathrm{~cm}$ of water was delivered at each time until SDS ratings were completed in both years. In Michigan, up to $2.5 \mathrm{~cm}$ of water per week was applied starting from emergence through R5 using an overhead pivot irrigation system. Fertilizer applications and other field operations were performed in each state following their state extension recommendations. Pre- and postemergence herbicides were used as needed at recommended rates to manage weeds.

The foliar treatments were applied using different spray equipment across the experimental locations. In Illinois, Indiana, Michigan, Ontario, and South Dakota, a backpack sprayer with a $\mathrm{CO}_{2}-$ pressurized tank and handheld boom equipped with four to six nozzles was used. In Illinois, four nozzles (TJ-60 8002VS) spaced $48 \mathrm{~cm}$ apart were fitted in a $150-\mathrm{cm}$ boom, which was calibrated to deliver 187 liters/ha at $276 \mathrm{kPa}$ of pressure. In Indiana, four TJ-VS $8001 \mathrm{noz}-$ zles spaced $51 \mathrm{~cm}$ apart were fitted in the $150-\mathrm{cm}$ boom and calibrated to deliver 140 liters/ha at $275 \mathrm{kPa}$ of pressure. In Michigan,

Table 2. List of treatments with application timings and rates that were applied in field experiments performed at Illinois, Indiana, Iowa, Michigan, South Dakota, and Wisconsin in the United States and Ontario, Canada during 2015 and 2016

\begin{tabular}{llll}
\hline SN & \multicolumn{1}{c}{ Treatments $^{\mathbf{z}}$} & Application method & Foliar application rate \\
\hline 1 & Syngenta base (SB) & Seed treatment & $\ldots$ \\
2 & SB + Pasteuria nishizawae + thiabendazole & Seed treatment & $\ldots$ \\
3 & Bayer base (BB) & Seed treatment & $\ldots$ \\
4 & BB + fluopyram + clothianidin + Bacillus firmus & Seed treatment & $\ldots$ \\
5 & BB + saponins extract of Chenopodium quinoa & Seed treatment & $\ldots$ \\
6 & BB fb lactofen & Foliar at R1 & \\
7 & BB fb fluoxastrobin + flutriafol & Foliar at R1 & $365 \mathrm{ml} / \mathrm{ha}$ \\
8 & BB fb citric acid & Foliar at R1 and R4 & \\
\hline
\end{tabular}

${ }^{\mathrm{z}}$ Treatments were SB that included a combination insecticide and fungicide active ingredients thiamethoxam + mefenoxam + fludioxonil + sedaxane $($ CruiserMaxx Vibrance; Syngenta Crop Protection LLC, Greensboro, NC, U.S.A.); SB + Pasteuria nishizawae Pn1 (Clariva; Syngenta Crop Protection LLC) + thiabendazole (Mertect 340-F; Syngenta Crop Protection LLC); BB = base seed treatment from Bayer CropScience, Research Triangle Park, NC, U.S.A. that included a combination of fungicide and insecticide active ingredients prothioconazole + penflufen + metalaxyl (Evergol Energy); metalaxyl (Allegiance) and imidacloprid + ethoxylated polyarylphenol (Gaucho); BB + fluopyram (ILeVO; BASF, Research Triangle Park, NC, U.S.A.) + clothianidin + Bacillus firmus (Poncho VOTiVO; BASF), BB + saponins extracted from Chenopodium quinoa (Heads Up; Heads Up Plant Protectants, Inc., Saskatchewan, Canada), BB followed by (fb) lactofen (Cobra; Valent U.S.A. Corporation, Walnut Creek CA, U.S.A.); BB fb fluoxastrobin + flutriafol (Fortix; Cheminova, Inc., Research Triangle Park, NC, U.S.A.); and BB fb citric acid (Procidic; Greenspire Global, Inc. Des Moines, IA, U.S.A.). Lactofen was applied with crop oil concentrate at $1,169 \mathrm{ml} / \mathrm{ha}$.

Table 3. Dates of planting, foliar treatment application, disease rating, and harvest for field experiments established in the states of Illinois, Indiana, Iowa, Michigan, South Dakota, and Wisconsin in the United States and Ontario, Canada during 2015 and $2016^{\mathrm{z}}$

\begin{tabular}{|c|c|c|c|c|c|c|c|}
\hline \multirow[b]{2}{*}{ Year, location } & \multirow[b]{2}{*}{ DOP } & \multicolumn{2}{|c|}{ Application GS } & \multirow[b]{2}{*}{ RR rating } & \multirow[b]{2}{*}{ SDS rating } & \multirow[b]{2}{*}{ GS } & \multirow[b]{2}{*}{ Harvest } \\
\hline & & $\mathbf{R 1}$ & R4 & & & & \\
\hline \multicolumn{8}{|l|}{2015} \\
\hline Ames, IA & 19 Apr & $15 \mathrm{Jul}$ & 4 Aug & 10 Aug & 27 Aug & R5.8 & $22 \mathrm{Sep}$ \\
\hline Roland, IA & 13 May & $15 \mathrm{Jul}$ & 4 Aug & 19 Aug & $11 \mathrm{Sep}$ & R6.0-R6.5 & 9 Oct \\
\hline Dixon Springs, IL & 2 May & 22 Jun & $15 \mathrm{Jul}$ & 22 Jun & $21 \mathrm{Aug}$ & R6.0 & 17 Oct \\
\hline Wanatah, IN & 1 Jun & $21 \mathrm{Jul}$ & 11 Aug & 12 Aug & $9 \mathrm{Sep}$ & R6.0 & 19 Oct \\
\hline Decatur, MI & 1 May & 29 Jun & $15 \mathrm{Jul}$ & $17 \mathrm{Jul}$ & 20 Aug & R6.0-R6.5 & $2 \mathrm{Oct}$ \\
\hline Highgate, ON & 11 May & $27 \mathrm{Jul}$ & 16 Aug & 10 Aug & 2 Sep & R6.0-R6.5 & 2 Oct \\
\hline Rodney, ON & 15 May & $27 \mathrm{Jul}$ & 16 Aug & $11 \mathrm{Aug}$ & $11 \mathrm{Sep}$ & R6.0-R6.5 & $13 \mathrm{Oct}$ \\
\hline \multicolumn{8}{|l|}{2016} \\
\hline Ames, IA & 6 May & 30 Jun & 9 Aug & 17 Aug & $1 \mathrm{Sep}$ & R6.0 & $28 \mathrm{Sep}$ \\
\hline Roland, IA & 6 May & 30 Jun & 15 Aug & 17 Aug & 1 Sep & $\mathrm{R} 5.8$ & $14 \mathrm{Oct}$ \\
\hline Wanatah, IN & 23 May & $2 \mathrm{Jul}$ & 4 Aug & $5 \mathrm{Aug}$ & $6 \mathrm{Sep}$ & R6.0 & $10 \mathrm{Oct}$ \\
\hline Decatur, MI & 9 May & NA & $\mathrm{NA}$ & NA & 23 Aug & R6.0 & 4 Oct \\
\hline Beresford, SD & 20 May & $22 \mathrm{Jul}$ & 10 Aug & 17 Aug & NA & NA & 24 Oct \\
\hline Arlington, WI & 19 May & $6 \mathrm{Jul}$ & 4 Aug & NA & NA & NA & $11 \mathrm{Oct}$ \\
\hline Highgate, ON & 31 May & $19 \mathrm{Jul}$ & 15 Aug & 17 Aug & 31 Aug & R6.0 & 13 Oct \\
\hline
\end{tabular}

${ }^{\mathrm{z}}$ Abbreviations: GS = growth stages (R1 = beginning bloom, R4 = full pod, R5 = beginning seed, and R6 = full seed), DOP = date of planting, RR = root rot, SDS = sudden death syndrome, Jun = June, Jul $=$ July, Aug = August, Sep $=$ September, Oct $=$ October, and NA $=$ not available. 
the spray boom consisted of six nozzles (TeeJet 11001VS) spaced $51 \mathrm{~cm}$ apart and was calibrated to apply 140 liters/ha. In Ontario and South Dakota, a $120-\mathrm{cm}$ handheld boom with four 8002 VS TeeJet nozzles spaced at $30 \mathrm{~cm}$ apart was calibrated to deliver 140 liters/ ha at $241 \mathrm{kPa}$ of pressure. In Iowa, foliar treatments were applied using a self-propelled small research plot sprayer equipped with six flat-fan nozzles (TeeJet $11015 \mathrm{XR}$ ). Nozzles were spaced $51 \mathrm{~cm}$ apart, which delivered 140 liters/ha at a pressure of $241 \mathrm{kPa}$. In Wisconsin, foliar treatments were applied using a $305-\mathrm{cm}$ handheld boom equipped with eight flat-fan nozzles (TeeJet $8002 X R$ ). Nozzles were spaced $38 \mathrm{~cm}$ apart and delivered 187 liters $/ \mathrm{ha}$ at $220 \mathrm{kPa}$ of pressure.

Plant population, root rot severity, foliar SDS incidence and severity, yield, and moisture data were collected from each field experiment. The number of live plants was counted to calculate plant population from either a 3-m section or the entire two to four rows of each plot at early vegetative growth stages (V2 to V3) (Fehr et al. 1971). At approximately the R4 growth stage, 10 to 12 plants from outside rows (nonyield rows) were collected, roots were washed, and root rot severity was visually estimated as a percentage of root area with brown discoloration or with lesions. Root rot data were not collected at the Dixon Springs, IL location in 2015. Foliar SDS incidence and severity were recorded between R5 and R6 growth stages (Table 3). Foliar disease incidence (DI) was estimated as the percentage of plants with foliar symptoms in the middle two rows of each plot, and disease severity (DS) was recorded on a 1to- 9 scale based on area of chlorotic or necrotic lesions on the leaf and premature defoliation, where $1=1$ to $10 \%$ leaf surface chlorotic or 1 to $5 \%$ necrotic and $9=$ premature plant death (Gibson et al. 1994). Foliar SDS disease index (FDX) was calculated from DI and DS by using the following formula: $\mathrm{FDX}=\mathrm{DI} \times \mathrm{DS} / 9$. At or shortly after full maturity (R8) (Table 3 ), the two middle rows of each plot were harvested with a small plot combine, and yields were calculated and adjusted to $13 \%$ moisture.

Data analysis was performed using SAS (version 9.4; SAS Institute, Inc., Cary, NC, U.S.A.). Mixed-model analysis of variance was performed using PROC GLIMMIX for all measured variables. Treatment and cultivar were defined as fixed effects; location and replication within a location were used as random effects. Statistical models are given below by equation 1 (cultivars were combined) and equation 2 (cultivars were separate). Treatment least square means were obtained using the lsmeans statement. Fisher's protected least significant difference was used to compare treatment means at $\alpha=$ 0.05 . For root rot, only the five seed treatments were analyzed, excluding treatments containing foliar applications.

$$
\begin{gathered}
Y_{i j k r}=\theta+L_{i}+\alpha_{j}+\beta_{k}+b(L)_{i r}+\alpha \beta_{j k}+e_{i j k r} \\
L_{i} \sim N\left[0, \sigma_{(L)} 2\right], b(L)_{i r} \sim N\left[0, \sigma_{b(L)} 2\right], \text { and } e_{i j k r} \sim N\left(0, \sigma_{e} 2\right)
\end{gathered}
$$

where $Y=$ response (dependent) variable for the $i$ th level of location, $j$ th level of cultivar, $k$ th level of crop protection products, and $r$ th level of block at $i$ th level of location; $\theta=$ constant (intercept); $L_{i}=$ effect of the $i$ th level of location (random effect); $\alpha_{j}=$ effect of the $j$ th level of cultivar (fixed effect); $\beta_{k}=$ effect of the $k$ th level of crop protection products (fixed effect); $b(L)_{i r}=$ effect of the $r$ th level of block at $i$ th level of location (random effect); $\alpha \beta_{j k}=$ interaction effect (effect of $j$ th level of cultivar and $k$ th level of crop protection product, fixed effect); and $e_{i j k r}=$ residual error.

$$
\begin{gathered}
Y_{i j k}=\theta+L_{i}+\alpha_{j}+b(L)_{i k}+e_{i j k} \\
L_{i} \sim N\left[0, \sigma_{(L)} 2\right], b(L)_{i k} \sim N\left[0, \sigma_{b(L)} 2\right], \text { and } e_{i j k} \sim N\left(0, \sigma_{e} 2\right)
\end{gathered}
$$

where $Y=$ response (dependent) variable for the $i$ th level of location, $j$ th level of crop protection products, and $k$ th level of block at $i$ th level of location; $\theta=$ constant (intercept); $L_{i}=$ effect of the $i$ th level of location (random effect); $\alpha_{j}=$ effect of the $j$ th level of crop protection products (fixed effect); $b(L)_{i k}=$ effect of the $k$ th level of block at the $i$ th level of location (random effect); and $\mathrm{e}_{i j k}=$ residual error.

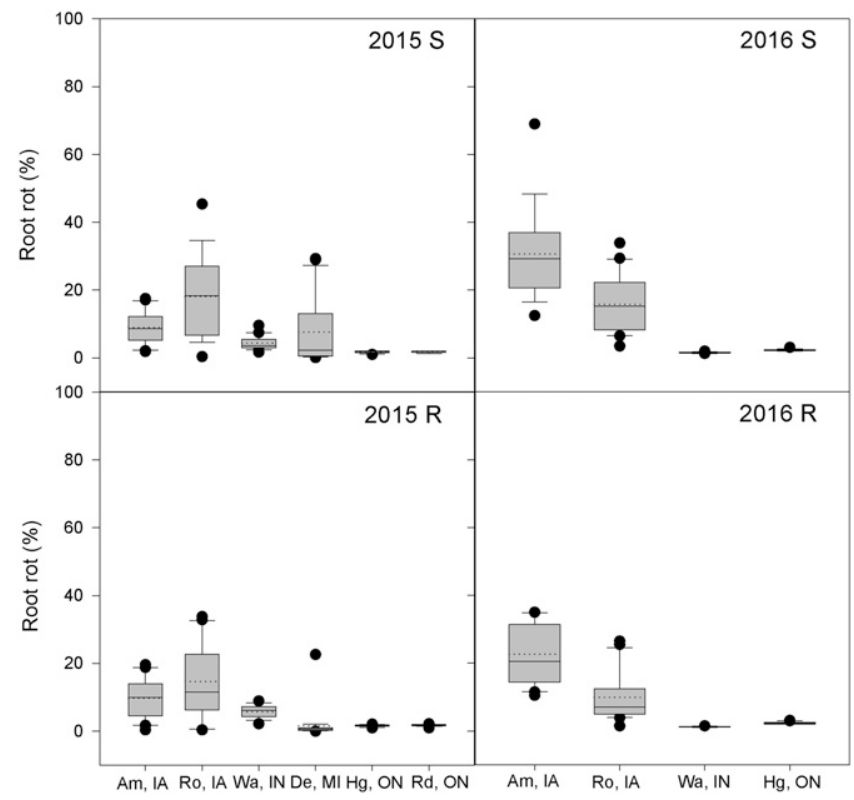

Fig. 1. Box plots of the distribution of root rot raw data from experimental plots grouped by year and cultivar ( $\mathrm{S}=$ susceptible and $\mathrm{R}=$ resistant to sudden death syndrome). Solid lines within a box represent the median and broken lines represent the mean. Top and bottom lines of the boxes are 75th and 25th percentiles, respectively, and the vertical lines extending the box are 90th and 10th percentiles. Locations: Am, $I A=$ Ames, IA; Ro, IA = Roland, IA; Wa, IN = Wanatah, IN; De, MI = Decatur, MI;

\begin{tabular}{|c|c|c|c|c|c|c|}
\hline \multirow[b]{3}{*}{ Treatments } & \multicolumn{6}{|c|}{ Plant population (number of plants/ha) } \\
\hline & \multicolumn{3}{|c|}{2015} & \multicolumn{3}{|c|}{2016} \\
\hline & $\mathbf{S}$ & $\mathbf{R}$ & Mean & $\mathbf{S}$ & $\mathbf{R}$ & Mean \\
\hline Syngenta base (SB) & $301,583 \mathrm{~b}$ & $306,928 \mathrm{a}$ & 307,829 a & $312,611 \mathrm{a}$ & $295,767 \mathrm{a}$ & $304,178 \mathrm{a}$ \\
\hline $\mathrm{SB}+$ Pasteuria nishizawae + thiabendazole & $303,387 \mathrm{~b}$ & $305,808 \mathrm{a}$ & 307,889 a & $314,580 \mathrm{a}$ & $295,152 \mathrm{a}$ & $304,545 \mathrm{a}$ \\
\hline Bayer base (BB) & $297,753 \mathrm{~b}$ & $279,546 \mathrm{~b}$ & $288,692 b$ & $283,411 b$ & $262,648 \mathrm{~b}$ & $273,019 \mathrm{~b}$ \\
\hline $\mathrm{BB}+$ fluopyram + clothianidin + Bacillus firmus & $323,380 \mathrm{a}$ & $307,118 \mathrm{a}$ & $315,291 \mathrm{a}$ & $288,475 \mathrm{~b}$ & $283,455 \mathrm{a}$ & $285,954 \mathrm{~b}$ \\
\hline $\mathrm{BB}+$ saponins extract of Chenopodium quinoa & $295,752 \mathrm{~b}$ & $285,239 \mathrm{ab}$ & $290,271 \mathrm{~b}$ & $279,428 \mathrm{~b}$ & $275,501 \mathrm{ab}$ & $277,332 \mathrm{~b}$ \\
\hline Mean & 307,749 A & 296,239 B & $\ldots$ & $295,505 \mathrm{~A}$ & 282,506 B & $\ldots$ \\
\hline$P>\mathrm{F}$ & 0.009 & 0.043 & $<0.01$ & 0.001 & 0.008 & $<0.01$ \\
\hline
\end{tabular}
$\mathrm{Hg}, \mathrm{ON}=$ Highgate, ON; and $\mathrm{Rd}, \mathrm{ON}=$ Rodney, ON

Table 4. Least square means of the plant population recorded in susceptible (S) and resistant $(\mathrm{R})$ cultivars in the field experiments carried out in the states of Illinois, Indiana, Iowa, Michigan, South Dakota, and Wisconsin in the United States and Ontario, Canada during 2015 and $2016^{\mathrm{z}}$

${ }^{\mathrm{z}}$ Means were compared using Fisher's protected least significant difference at $\alpha=0.05$. Means followed by the same lowercase letter within a column and the same uppercase letter between two cultivars within a year do not differ significantly. 


\section{Results}

Plant population. In 2015, plant population was affected by seed treatment in both resistant and susceptible cultivars (Table 4). Bayer base + fluopyram + clothianidin $+B$. firmus had greater plant populations compared with all other treatments in the susceptible cultivar. However, in the resistant cultivar, Bayer base + fluopyram + clothianidin $+B$. firmus resulted in greater plant population compared with the Bayer base seed treatment only. Plant populations were similar across all other treatments in the resistant cultivar (Table 4). Bayer base + fluopyram + clothianidin + B. firmus resulted in greater plant population than the Bayer base in susceptible $(8.6 \%)$ and resistant cultivars $(9.9 \%)$ (Table 4$)$.

In 2016, the highest plant populations were recorded in Syngenta base and Syngenta base $+P$. nishizawae + thiabendazole in the susceptible cultivar. All other treatments in the susceptible cultivar had statistically similar plant populations. In the resistant cultivar, the lowest plant population was observed in the Bayer base treatment, while the other treatments were not statistically different from each other (Table 4). The cultivar-treatment interaction was not statistically significant in any year. Resistant cultivars had $3.7 \%$ lower plant populations than the susceptible cultivars in 2015 and $4.4 \%$ lower in 2016.

Root rot severity. Box plots showing the distribution of root rot raw data in both cultivars across the experiment locations and years are given in Figure 1. In 2015, root rot severity was below $10 \%$ in control treatments in both cultivars (Table 5). The treatment effect for root rot was significant for the susceptible cultivars only (Table 5). Bayer base + fluopyram + clothianidin + B. firmus reduced root rot compared with Syngenta base and Bayer base + saponins extract of C. quinoa. Bayer base + fluopyram + clothianidin $+B$. firmus, Syngenta base $+P$. nishizawae + thiabendazole, and Bayer base had statistically similar levels of root rot in the susceptible cultivar. (Table 5).

In 2016, the susceptible cultivar had a root rot severity of $15.6 \%$ for the Syngenta base and $13.7 \%$ for the Bayer base seed treatments. Treatment affected root rot severity in both cultivars (Table 5 ). In the susceptible cultivar, Bayer base + fluopyram + clothianidin $+B$. fir mus reduced root rot compared with Bayer base, Syngenta base, and Syngenta base $+P$. nishizawae + thiabendazole; however, Bayer base + fluopyram + clothianidin + B. firmus and Bayer base + saponins extract of $C$. quinoa had similar levels of root rot. In the resistant cultivar, Bayer base + fluopyram + clothianidin + B. firmus reduced root rot compared with Bayer base, Bayer base + saponins extract of C. quinoa, and Syngenta base $+P$. nishizawae + thiabendazole; however, Bayer base + fluopyram + clothianidin $+B$. firmus and Syngenta base had similar root rot levels.

Bayer base + fluopyram + clothianidin + B. firmus reduced root rot severity by $53 \%$ in susceptible and by $45 \%$ in resistant cultivars compared with the Bayer base, which showed a root rot severity of $13.7 \%$ in susceptible and $11.7 \%$ in resistant cultivars. (Table 5). The cultivar-treatment interaction was not significant in any year.
FDX. Foliar SDS symptoms were observed at moderate to high levels in susceptible cultivars at many locations, indicating that conditions were favorable for SDS development in both years (Fig. 2) and FDX was not statistically different between the 2 years $(P=$ 0.68). Other foliar and stem diseases, including those with similar symptoms to SDS such as brown stem rot (caused by Cadophora gregata) and southern stem canker (caused by Diaporthe aspalathi), were not observed in any of the trials.

The treatment effect was significant for FDX in both resistant and susceptible cultivars in both years (Table 6). In 2015, the overall FDX in susceptible cultivars was 17.9 in Bayer base and 21.8 in Syngenta base. The Bayer base + fluopyram + clothianidin + B. firmus seed treatment had the lowest FDX among all treatments in the susceptible cultivars, with a $50 \%$ reduction compared with Bayer base. No significant difference between the Syngenta base and Syngenta base $+P$. nish$i z a w a e+$ thiabendazole seed treatment was observed in any cultivar. Similarly, Bayer base + saponins of $C$. quinoa and foliar applications with lactofen, fluoxastrobin + flutriafol, and citric acid did not result

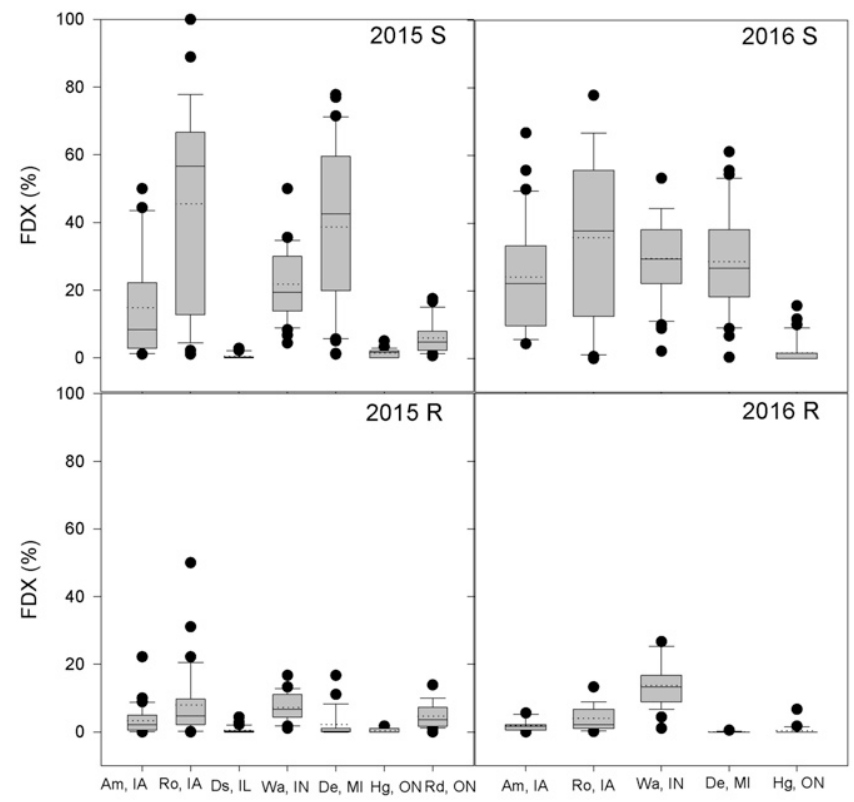

Fig. 2. Box plots of the distribution of foliar disease index (FDX $=$ disease incidence $x$ disease severity/9) from experimental plots grouped by year and cultivar ( $\mathrm{S}=$ susceptible and $\mathrm{R}=$ resistant to sudden death syndrome). Solid lines within a box represent the median and broken lines represent the mean. Top and bottom lines of the boxes are 75th and 25th percentiles, respectively, and the vertical lines extending the box are 90th and 10th percentiles. Locations: Am, IA = Ames, IA; Ro, IA = Roland, IA; Ds, IL = Dixon Springs, IL; Wa, IN = Wanatah, IN; De, MI = Decatur, Ml; Hg, ON = Highgate, ON; and Rd, ON = Rodney, ON.

Table 5. Least square means of the root rot recorded in susceptible (S) and resistant (R) cultivars in the field experiments carried out in the states of Illinois, Indiana, Iowa, Michigan, South Dakota, and Wisconsin in the United States and Ontario, Canada during 2015 and $2016^{\mathrm{z}}$

\begin{tabular}{|c|c|c|c|c|c|c|}
\hline \multirow[b]{3}{*}{ Treatments } & \multicolumn{6}{|c|}{ Root rot $(\%)$} \\
\hline & \multicolumn{3}{|c|}{2015} & \multicolumn{3}{|c|}{2016} \\
\hline & $\mathbf{S}$ & $\mathbf{R}$ & Mean & $\mathbf{S}$ & $\mathbf{R}$ & Mean \\
\hline Syngenta base (SB) & $9.3 \mathrm{a}$ & 6.7 & $8.3 \mathrm{a}$ & $15.3 \mathrm{a}$ & $8.7 \mathrm{ab}$ & $12.0 \mathrm{a}$ \\
\hline $\mathrm{SB}+$ Pasteuria nishizawae + thiabendazole & $8.3 \mathrm{ab}$ & 6.3 & $7.5 \mathrm{a}$ & $14.8 \mathrm{a}$ & $9.5 \mathrm{a}$ & $12.0 \mathrm{a}$ \\
\hline Bayer base (BB) & $6.6 \mathrm{ab}$ & 6.2 & $6.5 \mathrm{a}$ & $13.7 \mathrm{a}$ & $11.7 \mathrm{a}$ & $12.7 \mathrm{a}$ \\
\hline $\mathrm{BB}+$ fluopyram + clothianidin + Bacillus firmus & $4.2 \mathrm{~b}$ & 4.0 & $4.3 \mathrm{~b}$ & $8.4 \mathrm{~b}$ & $5.5 \mathrm{~b}$ & $7.0 \mathrm{~b}$ \\
\hline $\mathrm{BB}+$ saponins extract of Chenopodium quinoa & $9.3 \mathrm{a}$ & 6.1 & $7.8 \mathrm{a}$ & $10.7 \mathrm{ab}$ & $9.9 \mathrm{a}$ & $10.2 \mathrm{a}$ \\
\hline Mean & $7.9 \mathrm{~A}$ & $5.9 \mathrm{~B}$ & $\ldots$ & $12.5 \mathrm{~A}$ & $9.0 \mathrm{~B}$ & $\ldots$ \\
\hline$P>\mathrm{F}$ & 0.042 & 0.166 & 0.002 & 0.045 & 0.016 & $<0.01$ \\
\hline
\end{tabular}

${ }^{\mathrm{z}}$ Means were compared using Fisher's protected least significant difference at $\alpha=0.05$. Means followed by the same lowercase letter within a column and the same uppercase letter between two cultivars within a year do not differ significantly. 
in lower FDX than the Bayer base alone in susceptible cultivars (Table 6). Disease levels were overall much lower in resistant cultivars, with an overall FDX in Bayer base of 3.1\% and in Syngenta base of $3.8 \%$. In resistant cultivars, Bayer base + fluopyram + clothianidin $+B$. firmus and Bayer base fb lactofen had lower FDX than Syngenta base $+P$. nishizawae + thiabendazole and Bayer base $\mathrm{fb}$ citric acid. All other treatments were statistically similar.

In 2016, no SDS symptoms were observed in Beresford, SD and Arlington, WI, whereas all other locations recorded over 25\% FDX in Bayer base and Syngenta base in susceptible cultivars, except Highgate, ON (FDX $<5 \%)$. In the susceptible cultivar, Bayer base + fluopyram + clothianidin $+B$. firmus reduced FDX by $41 \%$ compared with Bayer base alone. Foliar products did not affect FDX when compared with Bayer base. Bayer base + fluopyram + clothianidin $+B$. firmus had lower levels of FDX compared with all treatments, except Bayer base + saponins extract of $C$. quinoa and Bayer base fb lactofen. (Table 6). In the resistant cultivar, disease severity was much lower compared with the susceptible cultivar, with an average FDX of 4.1 in the Bayer base and 4.3 in the Syngenta base treatments. Bayer base + fluopyram + clothianidin $+B$. firmus reduced FDX compared with all treatments except Bayer base fb lactofen. No foliar products reduced disease compared with Bayer base alone (Table 6).

Cultivars were significantly different for FDX in both years $(P<$ 0.01 ). Resistant cultivars reduced FDX by $75 \%$ in 2015 and by $84 \%$ in 2016 , compared with the susceptible cultivars, which had 18.9 FDX in 2015 and 24.1 in 2016 (Table 6). Cultivar-treatment interaction was not statistically significant in any year.

Yield. In 2015, treatment significantly affected grain yield in the susceptible cultivar (Table 7). In the susceptible cultivar, the Bayer base + fluopyram + clothianidin $+B$. firmus seed treatment had the highest yield, with an $8.9 \%$ increase over the Bayer base treatment. (Table 7). Bayer base fb lactofen treatment had significantly lower yield compared with all other treatments. All other treatments had similar yields. (Table 7). In the resistant cultivars, treatment effect was marginally significant $(P=0.061)$.

In 2016, soybean yield was greater than 2015 , although similar levels of SDS were observed in both years. Treatments affected grain yield only in the resistant cultivar (Table 7). Syngenta base had statistically greater yield than the Bayer base, Bayer base fb lactofen, Bayer base + saponins of $C$. quinoa, and Bayer base fb citric acid. Syngenta base and Syngenta base $+P$. nishizawae + thiabendazole were not statistically different and no foliar treatments resulted in greater yield than the Bayer base treatment.

The cultivar-treatment interaction was not statistically significant in any year. Resistant cultivars produced a greater yield in both years, with an increase of $11 \%$ in 2015 and $10 \%$ in 2016 over the susceptible cultivars, which produced $3,451 \mathrm{~kg} / \mathrm{ha}$ in 2015 and $4,629 \mathrm{~kg} / \mathrm{ha}$ in 2016 .

\section{Discussion}

Overall, fluopyram was the most effective treatment for SDS management, supporting previous studies (Gaspar et al. 2017; Kandel et al. 2016a,b, 2018a,b; Vosberg et al. 2017). None of the other fungicide or biological seed treatments evaluated in this study were significantly better than their respective base seed treatment in terms of their ability to reduce root rot and foliar symptoms of SDS. The disease response to fluopyram, as reflected by percent reduction in root rot and FDX, was not significantly different between susceptible and resistant cultivars. However, the yield benefit was greater in susceptible cultivars than resistant cultivars in 2015. A previous report analyzing over 200 studies from multiple field experiments also reported that the disease and yield response to fluopyram was not influenced by cultivar susceptibility; however, disease severity greatly influenced the yield response to fluopyram, with a greater yield response in higher disease conditions (Kandel et al. 2018a).

Resistant cultivars resulted in lower root rot, lower FDX, and greater yield than the susceptible cultivars, which is similar to what has been reported previously (Kandel et al. 2016b); however, in this study, the resistant cultivars performed better than the previous evaluations (Kandel et al. 2016b). There were significant differences between the susceptible and resistant cultivars in FDX (above 75\% in both years) and yield (above 10\%) in this study. The cultivar reaction to foliar symptoms of SDS was also consistent across the locations and follows the company ratings for these cultivars. These results reinforce the integrated pest management concept that the selection of a cultivar with SDS resistance is the primary management strategy for SDS. However, under high disease pressure, resistant cultivars may result in a level of disease similar to susceptible cultivars and suffer a significant yield loss (Kandel et al. 2016b). In addition, some resistance QTL that confer resistances against leaf symptoms are not associated with decreased root rot (Njiti et al. 1998). Those cultivars that are advertised as moderately resistant to SDS may not have resistance to early season root rot, which can also reduce yield due to poorly developed root systems. Therefore, under some circumstances, coupling the use of the most resistant cultivar available with an efficacious seed treatment may be warranted.

Fluopyram seed treatment was followed by foliar application of lactofen at R1 to R2 in an attempt to reduce FDX. Although the overall mean was not statistically different from Bayer base, the lactofen treatment did show the same level of FDX as the fluopyram seed treatment and lower FDX than some other treatments in most cases, meaning it may also have some effect against SDS. Similarly, a previous study by Sanogo et al. (2000) also reported a reduction in foliar

Table 6. Least square means of the foliar disease index (FDX) recorded in susceptible (S) and resistant (R) cultivars in the field experiments carried out in the states of Illinois, Indiana, Iowa, Michigan, South Dakota, and Wisconsin in the United States and Ontario, Canada during 2015 and $2016^{y}$

\begin{tabular}{|c|c|c|c|c|c|c|}
\hline \multirow[b]{2}{*}{ Treatments $^{\mathrm{z}}$} & \multicolumn{3}{|c|}{2015} & \multicolumn{3}{|c|}{2016} \\
\hline & $\mathbf{S}$ & $\mathbf{R}$ & Mean & $\mathbf{S}$ & $\mathbf{R}$ & Mean \\
\hline Syngenta base (SB) & $21.8 \mathrm{ab}$ & $3.8 \mathrm{ab}$ & $14.1 \mathrm{a}$ & $31.7 \mathrm{a}$ & $4.3 \mathrm{ab}$ & $18.0 \mathrm{a}$ \\
\hline SB + Pasteuria nishizawae + thiabendazole & $21.4 \mathrm{ab}$ & $5.3 \mathrm{a}$ & $14.8 \mathrm{a}$ & $25.9 \mathrm{abc}$ & $4.1 \mathrm{ab}$ & $15.0 \mathrm{ab}$ \\
\hline Bayer base (BB) & $17.1 \mathrm{ab}$ & $3.1 \mathrm{ab}$ & $10.7 \mathrm{a}$ & $25.7 \mathrm{abc}$ & $4.1 \mathrm{ab}$ & $14.8 \mathrm{ab}$ \\
\hline $\mathrm{BB}+$ fluopyram + clothianidin + Bacillus firmus & $8.0 \mathrm{c}$ & $1.6 \mathrm{~b}$ & $5.0 \mathrm{~b}$ & $15.2 \mathrm{~d}$ & $1.7 \mathrm{c}$ & $8.4 \mathrm{c}$ \\
\hline BB + saponins extract of Chenopodium quinoa & $16.1 \mathrm{~b}$ & $5.2 \mathrm{a}$ & $11.0 \mathrm{a}$ & $20.6 \mathrm{bcd}$ & $4.9 \mathrm{ab}$ & $13.3 \mathrm{abc}$ \\
\hline BB followed by (fb) lactofen & $19.2 \mathrm{ab}$ & $2.0 \mathrm{~b}$ & $10.7 \mathrm{a}$ & $19.1 \mathrm{~cd}$ & $3.6 \mathrm{bc}$ & $11.3 \mathrm{bc}$ \\
\hline $\mathrm{BB}$ fb fluoxastrobin + flutriafol & $22.4 \mathrm{ab}$ & $4.0 \mathrm{ab}$ & $13.4 \mathrm{a}$ & $26.2 \mathrm{abc}$ & $3.8 \mathrm{~b}$ & $15.0 \mathrm{ab}$ \\
\hline BB fb citric acid & $24.1 \mathrm{a}$ & $5.0 \mathrm{a}$ & $14.7 \mathrm{a}$ & $27.6 \mathrm{ab}$ & $5.8 \mathrm{a}$ & $16.7 \mathrm{ab}$ \\
\hline Mean & $18.9 \mathrm{~A}$ & $4.7 \mathrm{~B}$ & $\ldots$ & $24.1 \mathrm{~A}$ & $4.0 \mathrm{~B}$ & $\ldots$ \\
\hline$P$ value & 0.002 & 0.015 & $<0.01$ & 0.001 & 0.010 & $<0.01$ \\
\hline
\end{tabular}

y Means were compared using Fisher's protected least significant difference at $\alpha=0.05$. Means followed by the same lowercase letter within a column and same uppercase letter between two cultivars within a year do not differ significantly. FDX of sudden death syndrome (SDS) was calculated combining disease incidence, estimated as percentage of plants with SDS symptoms per plot, and severity, scored on 1-to-9 scale based on the percentage of leaf area with chlorosis, necrosis, and premature defoliation.

${ }^{\mathrm{z}}$ Lactofen and fluoxastrobin + flutriafol were applied at R1 (beginning bloom) and citric acid was applied at R1 and R4 (full pod) growth stages. Other treatments were applied on seed as seed treatments. 
Table 7. Least square means of the soybean yield recorded in susceptible and resistant cultivars in the field experiments carried out in the states of Illinois, Indiana, Iowa, Michigan, South Dakota, and Wisconsin in the United States and Ontario, Canada during 2015 and $2016^{\mathrm{y}}$

\begin{tabular}{|c|c|c|c|c|c|c|}
\hline \multirow[b]{3}{*}{ Treatments $^{\mathbf{z}}$} & \multicolumn{6}{|c|}{ Yield (kg/ha) } \\
\hline & \multicolumn{3}{|c|}{2015} & \multicolumn{3}{|c|}{2016} \\
\hline & $\mathbf{S}$ & $\mathbf{R}$ & Mean & $\mathbf{S}$ & $\mathbf{R}$ & Mean \\
\hline Syngenta base (SB) & $3,468 \mathrm{~b}$ & 3,858 & $3,621 \mathrm{~b}$ & 4,618 & $5,238 \mathrm{a}$ & 4,929 \\
\hline SB + Pasteuria nishizawae + thiabendazole & $3,553 \mathrm{~b}$ & 3,713 & $3,596 \mathrm{~b}$ & 4,778 & $5,115 \mathrm{abc}$ & 4,952 \\
\hline Bayer base (BB) & $3,556 \mathrm{~b}$ & 3,872 & $3,712 \mathrm{ab}$ & 4,605 & $5,038 \mathrm{bcd}$ & 4,822 \\
\hline $\mathrm{BB}+$ fluopyram + clothianidin + Bacillus firmus & $3,904 \mathrm{a}$ & 4,012 & $3,956 \mathrm{a}$ & 4,650 & $5,226 \mathrm{ab}$ & 4,938 \\
\hline BB + saponins extract of Chenopodium quinoa & $3,472 \mathrm{~b}$ & 3,977 & $3,731 \mathrm{ab}$ & 4,688 & $4,943 \mathrm{~cd}$ & 4,813 \\
\hline BB followed by(fb) lactofen & $3,069 \mathrm{c}$ & 3,519 & $3,285 \mathrm{c}$ & 4,532 & $4,909 \mathrm{~d}$ & 4,722 \\
\hline BB fb fluoxastrobin + flutriafol & $3,509 \mathrm{~b}$ & 3,969 & $3,737 \mathrm{ab}$ & 4,682 & $5,109 \mathrm{abc}$ & 4,896 \\
\hline BB fb citric acid & $3,489 \mathrm{~b}$ & 3,794 & $3,639 \mathrm{~b}$ & 4,545 & $5,017 \mathrm{~cd}$ & 4,781 \\
\hline Mean & $3,451 \mathrm{~B}$ & $3,868 \mathrm{~A}$ & $\ldots$ & $4,629 \mathrm{~B}$ & $5,085 \mathrm{~A}$ & $\ldots$ \\
\hline$P$ value & 0.001 & 0.061 & $<0.01$ & 0.593 & $<0.01$ & 0.120 \\
\hline
\end{tabular}

y Means were compared using Fisher's protected least significant difference at $\alpha=0.05$. Means followed by the same lowercase letter within a column and same uppercase letter between two cultivars within a year do not differ significantly.

${ }^{\mathrm{z}}$ Lactofen and fluoxastrobin + flutriafol were applied at R1 (beginning bloom) and citric acid was applied at R1 and R4 (full pod) growth stages. Other treatments were applied on seed as seed treatments.

disease severity, frequency of $F$. virguliforme isolation from roots, conidial germination, mycelial growth, and sporulation by lactofen. Lactofen was also reported to be effective in reducing Sclerotinia stem rot and protecting soybean from yield loss due to this disease (Dann et al. 1999; Huzar-Novakowiski et al. 2017; Willbur et al. in press; Yang et al. 1998). Although lactofen has a potential benefit of controlling Sclerotinia stem rot and may have some effect on SDS, it produced the lowest yield. When combining all site-years, lactofen resulted in a yield loss of about $261 \mathrm{~kg} / \mathrm{ha}(6.1 \%)$ compared with the Bayer base. A similar result has also been reported in previous studies (Dann et al. 1999; Nelson and Renner 2001; Nelson et al. 2007; Willbur et al. in press), where a 10 to $15 \%$ yield reduction was reported when Sclerotinia stem rot did not develop. However, under high Sclerotinia stem rot pressure, lactofen was shown to effectively reduce damage caused by the disease and not negatively affect yield loss. While under low Sclerotinia stem rot severity, the damage from lactofen was greater than that from the disease and resulted in yield reductions over multiple site-year studies (Willbur et al. in press). Lactofen toxicity in plants reduces leaf area index, causes leaf distortion, and reduces plant height, which consequently delays reproductive development (Huzar-Novakowiski et al. 2017; Nelson et al. 2002) and is linked to a negative impact on yield in the absence of Sclerotinia stem rot. Some soybean farmers feel that lactofen application at the early-vegetative stage causes stress to the plants that leads to increased branch development and, subsequently, increased yield. Previous studies (Gregg et al. 2015; Mangialardi et al. 2016; Orlowski et al. 2016a,b) that investigated the effect of lactofen application at the early vegetative stage for yield purposes did not find any effect on soybean branching or yield.

Amendment of Syngenta base with $P$. nishizawae and thiabendazole did not provide any additional advantage in terms of reducing disease (root rot and FDX) or increasing yield than the Syngenta base. However, we did not evaluate their efficacy on SCN management in this study. Similarly, seed treatment with the saponins of C. quinoa and foliar applications of fluoxastrobin + flutriafol or citric acid did not reduce SDS significantly in any cultivars or years compared with Bayer base. In contrast, a previous study (Navi and Yang 2016b) has reported that saponins of $C$. quinoa significantly suppressed SDS in soybean compared with the untreated control. Saponins of $C$. quinoa were also reported as effective against other crop diseases such as dry rot, common scab, and black scurf diseases of potato (Al-Mugharabi et al. 2010).

Use of the fluopyram seed treatment has been a concern to some farmers due to the obvious phytotoxicity, which is particularly apparent on the cotyledons. Fluopyram has demonstrated some minor reductions in plant populations in some situations (Gaspar et al. 2017); however, the reduction in plant population has not been shown to affect yield (Kandel et al. 2016b). In this study, the fluopyram seed treatment did not result in lower plant populations than the Bayer base in any case; in fact, the fluopyram seed treatment resulted in increased plant populations by nearly 9 to $10 \%$ in resistant and susceptible cultivars compared the Bayer base seed treatment. This response might be due not only to fluopyram's ability to protect seedlings from $F$. virguliforme infection but also activity against other seedling pathogens, which were not evaluated in the present study. A previous report has shown the efficacy of fluopyram in controlling other diseases such as soybean brown leaf spot (Batzer et al. 2016). Similarly, the Syngenta base and Syngenta base + P. nishizawae + thiabendazole resulted in greater soybean plant populations than Bayer base in many cases, which may be due to a better control of seedling pathogens.

The use of resistant cultivars and the fluopyram seed treatment were the two most effective treatments in reducing SDS in our research. Fluopyram seed treatment is typically sold in combination with other seed treatment active ingredients and adds approximately U.S. $\$ 30$ to $32 /$ ha at the current price to the cost of the basic seed treatment. The use of fluopyram seed treatment as a management practice without incorporating plant resistance does not always provide a sufficient level of SDS control. Yield benefits associated with fluopyram seed treatment also varies among cultivars, locations, and years. Previous research demonstrated that the chance of not earning back the cost of the fluopyram seed treatment is high when no foliar disease symptoms are observed (Kandel et al. 2018a). Currently, there is no SDS forecasting system in place, meaning farmers cannot predict if SDS will develop in a particular season or field. Because the risk of economic loss is high in the absence of disease, a fluopyram seed treatment likely will not be warranted if the field has no history of SDS. Selectively using fluopyram seed treatment on high-risk fields may help to ensure a return on investment and preserve fungicide activity against $F$. virguliforme (Gaspar et al. 2017). The FRAC has categorized SDHI fungicides, including fluopyram, as medium risk for the development of fungicide resistance (FRAC 2017). Nonetheless, a fungicide resistance management plan must be taken into account because the repetitive use of a single modeof-action fungicide such as fluopyram may likely select isolates of $F$. virguliforme to have reduced sensitivity or resistance to fluopyram over time.

\section{Acknowledgments}

We thank Heads Up, Syngenta Crop Protection LLC., Cheminova, Inc., and Greenspire Global, Inc. for providing their products to test in this study; and K. Ames, J. Pike, and J. Weems from Illinois, N. Anderson and J. Ravellette from Indiana, S. Wiggs, C. Hunt, and D. Sjarpe from Iowa, A. Byrne and J. Boyse from Michigan, N. Braun and P. Okello from South Dakota, S. Chapman and B Mueller from Wisconsin, and C. Van Herk, G. Kotulak, and B. Jones from Ontario for their assistance with the field trials. 


\section{Literature Cited}

Allen, T. W., Bradley, C. A., Sisson, A. J., Byamukama, E., Chilvers, M. I., Coker, C. M., Collins, A. A., Damicone, J. P., Dorrance, A. E., Dufault, N. S., Esker, P. D., Faske, T. R., Giesler, L. J., Grybauskas, A. P., Hershman, D. E., Hollier, C. A., Isakeit, T., Jardine, D. J., Kemerait, R. C., Kleczewski, N. M., Koenning, S. R., Kurle, J. E., Malvick, D. K., Markell, S. G., Mehl, H. L., Mueller, D. S., Mueller, J. D., Mulrooney, R. P., Nelson, B. D., Newman, M. A., Osborne, L., Overstreet, C., Padgett, G. B., Phipps, P. M., Price, P. P., Sikora, E. J., Smith, D. L., Spurlock, T. N., Tande, C. A., Tenuta, A. U., Wise, K. A., Wrather, J. A., and Young-Kelly, H. 2017. Soybean yield loss estimates due to diseases in the United States and Ontario, Canada from 2010 to 2014. Plant Health Prog. 18:19-27.

Al-Mugharabi, K. I., Vikram, A., and Poirier, R. 2010. Effect of Saponins of Chenopodium quinoa applied as seed or foliar treatments on dry rot, common scab and black scurf diseases of potato. Am. J. Plant Sci. Biotechnol. 4:65-70.

Anderson, T. R., and Tenuta, A. U. 1998. First report of Fusarium solani f. sp. glycines causing sudden death syndrome of soybean in Canada. Plant Dis. 82:448.

Aoki, T., O’Donnell, K., Homma, Y., and Lattanzi, A. R. 2003. Sudden-death syndrome of soybean is caused by two morphologically and phylo genetically distinct species within the Fusarium solani species complex-F. virguliforme in North America and F. tucumaniae in South America. Mycologia 95:660-684.

Batzer, J. C., Kandel, Y. R., Bradley, C. A., Chilvers, M. I., Tenuta, A. U., Wise, K. A., Hernández, E., and Mueller, D. S. 2016. Effect of seed treatment on early season brown spot caused by Septoria glycines of soybean. Plant Health Prog. 17:223-228.

Brar, H. K., Swaminathan, S., and Bhattacharyya, M. K. 2011. The Fusarium virguliforme toxin FvTox1 causes foliar sudden death syndrome-like symptoms in soybean. Mol. Plant-Microbe Interact. 24:1179-1188.

Brzostowski, L. F., Pruski, T. I., Hartman, G. L., Bond, J. P., Wang, D., Cianzio, S. R., and Diers, B. W. 2018. Field evaluation of three sources of genetic resis tance to sudden death syndrome of soybean. Theor. Appl. Genet. 131:1541-1552.

Chang, H.-X., Domier, L. L., Radwan, O., Yendrek, C. R., Hudson, M. E., and Hartman, G. L. 2016. Identification of multiple phytotoxins produced by Fusarium virguliforme including a phytotoxic effector (FvNIS1) associated with sudden death syndrome foliar symptoms. Mol. Plant-Microbe Interact. 29:96-108.

Chang, H.-X., Roth, R., Wang, D., Lightfoot, D., Hartman, G., Ciazano, S., and Chilvers, M. I. 2018. Integration of sudden death syndrome resistance loci in the soybean genome. Theor. Appl. Genet. 131:757-773.

Dann, E. K., Diers, B. W., and Hammerschmidt, R. 1999. Suppression of Sclerotinia stem rot of soybean by lactofen herbicide treatment. Phyto pathology 89:598-602.

de Farias Neto, A. L., Hartman, G. L., Pedersen, W. L., Li, S., Bollero, G. A., and Diers, B. W. 2006. Irrigation and inoculation treatments that increase the severity of soybean sudden death syndrome in the field. Crop Sci. 46:2547-2554.

Fehr, W. R., Caviness, C. E., Burmood, D. T., and Pennington, J. S. 1971. Stage of development descriptions for soybeans, Glycine max (L.). Merrill. Crop Sci. 11:929-931.

FRAC. 2017. Fungicide Resistance Action Committee Code List 2017. Fungi cides sorted by mode of action. http://www.frac.info/publications/accept

Gaspar, A. P., Chilvers, M. I., Wise, K. A., Tenuta, A. U., Mueller, D. S., and Conley, S. P. 2017. Response of broad spectrum and target specific seed treatments and seeding rate on soybean seed yield, profitability, and eco nomic risk across diverse environments. Crop Sci. 57:2251-2262.

Gibson, P., Shenaut, M., Njiti, V., Suttner, R., and Myers, O., Jr. 1994. Soybean varietal response to sudden death syndrome. Pages 20-40 in: Proc. 24th Soybean Seed Res. Conf. Chicago. D. Wilkinson, ed. American Seed Trade Association, Washington, DC.

Gongora-Canul, C., and Leandro, L. F. S. 2011. Plant age affects root infection and development of foliar symptoms of soybean sudden death syndrome. Plant Dis. 95:242-247.

Gregg, G. L., Orlowski, J. M., and Lee, C. D. 2015. Input-based stress management fails to increase soybean yield in Kentucky. Crop Forage Turfgrass Manage. 1.

Hartman, G. L., Chang, H. X., and Leandro, L. F. 2015a. Research advances and management of soybean sudden death syndrome. Crop Prot. 73:60-66.

Hartman, G. L., Leandro, L. F. S., and Rupe, J. C. 2015b. Sudden death syndrome. Pages 88-90 in: Compendium of Soybean Disease and Pests. G. L. Hartman, J. C. Rupe, E. F. Sikora, L. L. Domier, J. A. Davis, and K. L. Steffey, eds. American Phytopathological Society, St. Paul, MN, U.S.A.

Hirrel, M. C. 1983. Sudden death syndrome of soybean-A disease of unknown etiology. (Abstr.) Phytopathology 73:501.

Huang, Y. H., and Hartman, G. L. 1998. Reaction of selected soybean genotypes to isolates of Fusarium solani f. sp. glycines and their culture filtrates. Plant Dis. 82:999-1002.

Huzar-Novakowiski, J., Paul, P. A., and Dorrance, A. E. 2017. Host resistance and chemical control for management of Sclerotinia stem rot of soybean in Ohio. Phytopathology 107:937-949.

Kandel, Y. R., Leandro, L. F. S., and Mueller, D. S. 2019. Effect of tillage and cultivar on plant population, sudden death syndrome, and yield of soybean in Iowa. Plant Health Prog. 20:29-34.
Kandel, Y. R., McCarville, M., Adee, E. A., Bond, J. P., Chilvers, M. I., Conley, S. P., Giesler, L. J., Kelly, H. M., Malvick, D., Mathew, F. M., Rupe, J. C., Sweets, L., Tenuta, A., Wise, K. A., and Mueller, D. S. 2018a. Benefits and profitability of fluopyram-amended seed treatments for suppressing sudden death syndrome and protecting soybean yield: A meta-analysis. Plant Dis. 102:1093-1100.

Kandel, Y. R., Mueller, D. S., Legleiter, T., Johnson, W. G., Young, B. G., and Wise, K. A. 2018b. Impact of fluopyram fungicide and preemergence herbicides on soybean injury, population, sudden death syndrome, and yield. Crop Prot. 106:103-109.

Kandel, Y. R., Wise, K. A., Bradley, C. A., Chilvers, M. I., Byrne, A. M., Tenuta, A. U., Faghihi, J., Wiggs, S. N., and Mueller, D. S. 2017. Effect of soybean cyst nematode resistance source and seed treatment on population densities of Heterodera glycines, sudden death syndrome, and yield of soybean. Plant Dis. 101:2137-2143.

Kandel, Y. R., Wise, K. A., Bradley, C. A., Chilvers, M. I., Tenuta, A. U., and Mueller, D. S. 2016a. Fungicide and cultivar effects on sudden death syndrome and yield of soybean. Plant Dis. 100:1339-1350.

Kandel, Y. R., Wise, K. A., Bradley, C. A., Tenuta, A. U., and Mueller, D. S. 2016b. Effect of planting date, seed treatment, and cultivar on plant population, sudden death syndrome, and yield of soybean. Plant Dis. 100: 1735-1743.

Koenning, S. R., and Wrather, J. A. 2010. Suppression of soybean yield potential in the continental United States by plant diseases from 2006 to 2009. Plan Health Prog. 11.

Leandro, L. F., Tatalovic, N., and Luckew, A. 2012. Soybean sudden death syndrome-Advances in knowledge and disease management. CAB Rev. 7: $1-14$.

Leandro, L. F. S., Eggenberger, S., Chen, C., Williams, J., Beattie, G. A., and Liebman, M. 2018. Cropping system diversification reduces severity and incidence of soybean sudden death syndrome caused by Fusarium virguliforme. Plant Dis. 102:1748-1758.

Mangialardi, J. P., Orlowski, J. M., Lawrence, B. H., Bond, J. A., Golde, B. R., Catchot, A., Peeples, J. D., and Eubank, T. W. 2016. Growth regulation with lactofen does not affect seed yield of irrigated soybean. Agron. J. 108: 1112-1115.

Marburger, D. A., Smith, D. L., and Conley, S. P. 2016. Revisiting planting date and cultivar effects on soybean sudden death syndrome development and yield loss. Plant Dis. 100:2152-2157.

McLean, K. S., and Lawrence, G. W. 1993. Interrelationship of Heterodera glycines and Fusarium solani in sudden death syndrome of soybean. J. Nematol. 25:434-439.

Melgar, J., Roy, K. W., and Abney, T. S. 1994. Sudden death syndrome of soybean: Etiology, symptomatology, and effects of irrigation and Heterodera glycines on incidence and severity under field conditions. Can. J. Bot. 72:1647-1653.

Navi, S. S., and Yang, X. B. 2016a. Impact of crop residue and corn-soybean rotation on the survival of Fusarium virguliforme a causal agent of sudden death syndrome of soybean. J. Plant Pathol. Microbiol. 7.

Navi, S. S., and Yang, X. B. 2016b. Sudden death syndrome-A growing threat of losses in soybean. CAB Rev. 11.

Nelson, K. A., and Renner, K. A. 2001. Soybean growth and development as affected by glyphosate and postemergence herbicide tank mixtures. Agron. J. 93:428-434.

Nelson, K. A., Renner, K. A., and Hammerschmidt, R. 2002. Cultivar and herbicide selection affects soybean development and the incidence of Sclerotinia stem rot. Agron. J. 94:1270-1281.

Nelson, K. A., Rottinghaus, G. E., and Nelson, T. E. 2007. Effect of lactofen application timing on yield and isoflavone concentration in soybean seed. Agron. J. 99:645-649.

Njiti, V., Doubler, T., Suttner, R. J., Gray, L., Gibson, P., and Lightfoot, D. 1998. Resistance to soybean sudden death syndrome and root colonization by Fusarium solani f. sp. glycine in near-isogenic lines. Crop Sci. 38:472-477.

Orlowski, J. M., Gregg, G. L., and Lee, C. D. 2016a. Early-season lactofen application has limited effect on soybean branch and mainstem yield com ponents. Crop Sci. 56:432-438

Orlowski, J. M., Haverkamp, B. J., Laurenz, R. G., Marburger, D. A., Wilson, E. W., Casteel, S. N., Conley, S. P., Naeve, S. L., Nafziger, E. D., Roozeboom, K. L., Ross, W. J., Thelen, K. D., and Lee, C. D. 2016b. High-input manage ment systems effect on soybean seed yield, yield components, and economic break-even probabilities. Crop Sci. 56:1988-2004.

Pudake, R. N., Swaminathan, S., Sahu, B. B., Leandro, L. F., and Bhattacharyya, M. K. 2013. Investigation of the Fusarium virguliforme fvtoxl mutants revealed that the FvTox 1 toxin is involved in foliar sudden death syndrome development in soybean. Curr. Genet. 59:107-117.

Roy, K., Lawrence, G., Hodges, H., McLean, K., and Killebrew, J. 1989. Sudden death syndrome of soybean: Fusarium solani as incitant and relation of Heterodera glycines to disease severity. Phytopathology 79:191-197.

Sanogo, S., Yang, X., and Scherm, H. 2000. Effects of herbicides on Fusarium solani f. sp. glycines and development of sudden death syndrome in glyphosate-tolerant soybean. Phytopathology 90:57-66.

Scherm, H., and Yang, X. 1996. Development of sudden death syndrome of soybean in relation to soil temperature and soil water matric potential. Phytopathology 86:642-649. 
Scherm, H., Yang, X., and Lundeen, P. 1998. Soil variables associated with sudden death syndrome in soybean fields in Iowa. Plant Dis. 82:1152-1157.

Vosberg, S. K., Marburger, D. A., Smith, D. L., and Conley, S. P. 2017. Planting date and fluopyram seed treatment effect on soybean sudden death syndrome and seed yield. Agron. J. 109:2570-2578.

Wang, J., Bradley, C. A., Stenzel, O., Pedersen, D. K., Reuter-Carlson, U., and Chilvers, M. I. 2017. Baseline sensitivity of Fusarium virguliforme to fluopyram fungicide. Plant Dis. 101:576-582.

Wang, J., Jacobs, J. L., Roth, M. G., and Chilvers, M. I. 2019. Temporal dynamics of Fusarium virguliforme colonization of soybean roots. Plant Dis. 103:19-27.

Weems, J. D., Haudenshield, J. S., Bond, J. P., Hartman, G. L., Ames, K. A., and Bradley, C. A. 2015. Effect of fungicide seed treatments on Fusarium virguliforme infection of soybean and development of sudden death syndrome. Can. J. Plant Pathol. 37:435-447.

Willbur, J. F., Mitchell, P. D., Fall, M. L., Byrne, A. M., Chapman, S. A., Floyd, C. M., Bradley, C. A., Ames, K. A., Chilvers, M. I., Kleczewski, N. M., Malvick,
D. K., Mueller, B. D., Mueller, D. S., Kabbage, M., Conley, S. P., and Smith, D. L. Meta-analytic and economic approaches for evaluation of pesticide im pact on Sclerotinia stem rot control and soybean yield in the North Central U.S. Phytopathology. In press. doi.org/10.1094/PHYTO-04-18-0124-R

Wrather, A., and Koenning, S. 2009. Effects of diseases on soybean yields in the United States 1996 to 2007. Plant Health Prog. 10.

Wrather, A., Shannon, G., Balardin, R., Carregal, L., Escobar, R., Gupta, G. K., Ma, Z., Morel, W., Ploper, D., and Tenuta, A. 2010. Effect of diseases on soybean yield in the top eight producing countries in 2006. Plant Health Prog. 11.

Xing, L., and Westphal, A. 2006. Interaction of Fusarium solani f. sp. glycines and Heterodera glycines in sudden death syndrome of soybean. Phytopathology 96 : 763-770.

Yang, X. B., Owen, M. D., and Hartzler, R. G. 1998. Cobra for white mold suppression. Integrated Crop Management News, Iowa State University Extension and Outreach, Ames. https://lib.dr.iastate.edu/cropnews/2307 